\title{
A COMPARISON OF THE SPANISH AND CANADIAN LAW OF SELF-DEFENCE
}

\author{
JAVIER VALLS PRIETO* AND WAYNE N. RENKE**
}

In this article, the rules for self-defence in Canada and Spain are compared and contrasted. We will offer an explanation for the recognition of self-defence, in its several forms; describe some formal similarities and differences between the two versions of the defence; and then compare and contrast the approaches of the defence under eight main themes - interests protected; threats to those interests; mistakes by the defender; time constraints on the defence; measuring conduct falling within the scope of statutory protection; the availability of the defence to a defender who provoked aggression; and the use of evidence that does not fully support the defence.
Les auteurs de cet article comparent et contrastent les règles canadiennes et espagnoles en matière de légitime défense. Les auteurs donnent une explication de la reconnaissance de la légitime défense dans ses formes multiples, et décrivent certaines similarités et différences officielles entre les deux versions de la défense. Ils comparent et contrastent ensuite les approches de la défense à la lumière de huit grands thèmes, c'est-à-dire les intérêts protégés, les menaces à ces intérêts, les fautes du défendeur, les limites de temps de la défense, le comportement accepté dans la portée de la protection réglementaire, la disponibilité de la défense au défendeur qui a provoqué l'agression et l'utilisation de preuve qui n'appuie pas entièrement la défense.

\section{TABLE OF CONTENTS}

I. INTRODUCTION . . . . . . . . . . . . . . . . . . . . . . . . . . . . . . . 853

II. The Defence of Self-Defence . . . . . . . . . . . . . . . . . . . . . . 854

A. Our State of Nature . . . . . . . . . . . . . . . . . . . 854

B. MORAL IMPLICATIONS OF THE BASIC FACTS $\ldots \ldots \ldots \ldots \ldots . \ldots 84$

III. FORMAL SIMILARITIES AND DIFFERENCES $\ldots \ldots \ldots \ldots \ldots \ldots \ldots \ldots . \ldots 85$

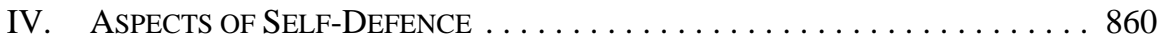

A. Interests PROtected $\ldots \ldots \ldots \ldots \ldots \ldots \ldots \ldots \ldots \ldots \ldots$

B. Threats to Interests $\ldots \ldots \ldots \ldots \ldots \ldots \ldots \ldots \ldots \ldots \ldots \ldots$

C. Mistake BY THE DEFENDER . . . . . . . . . . . . . . . . . . . . 869

D. Time Contraints . . . . . . . . . . . . . . . . . . 869

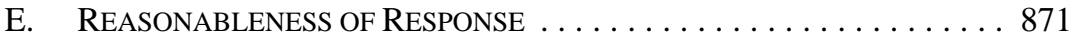

F. Provocation by the Defender . . . . . . . . . . . . . 873

G. IMPERFECT SELF-DEFENCE $\ldots \ldots \ldots \ldots \ldots \ldots \ldots \ldots \ldots \ldots$

V. Conclusion .................................. 875

\section{INTRODUCTION}

In Spain as in Canada, the criminal law permits killing in self-defence. Of course, this coincidence is less remarkable than would be its absence. It may also come as no surprise that while the two legal systems' self-defence rules address the same basic issues, the rules have both similarities and differences - although what we might find surprising and possibly illuminating are the particular ways in which the rules differ. We will offer an explanation for the recognition of the defence, in its several forms; describe some formal similarities and differences between the two versions of the defence; and then compare and 
contrast the approaches of the defence under eight main themes - interests protected; threats to those interests; mistakes by the defender; time constraints on the defence; measuring conduct falling within the scope of statutory protection; the availability of the defence to a defender who provoked aggression; and the use of evidence that does not fully support the defence.

\section{THE DEFENCE OF SELF-DefENCE}

Self-defence rests on some simple facts about the human condition - or at least the condition of those in the European cultural tradition which embraces Spain and Canada. The defence is internally complex, covering several morally distinct types of responses to aggression, and depends on the practical — if not theoretical — resolution of a moral paradox. Our intention here is not to offer a full theoretical assessment of self-defence, but to point to its moral foundations, which account for its inevitable occurrence in the two legal systems.

\section{A. Our State of Nature}

The set of facts that give rise to the practical necessity for recognizing the legitimacy of some form of self-defence are as follows: ${ }^{1}$ first, humans are disposed to engage in intraspecific violence. Violence may be a means to an end. It may be used, for example, to acquire the personal or real property of others. Violence may be an end in itself. Second, we are relatively fragile creatures, susceptible to injury as a result of violence. We lack the carapace that would permit us to ignore others' inclinations to violence. Third, at least in the short term, violent aggression often cannot be terminated except through violent response. Aggressors tend not to desist when asked or when an attempt is made to reason with them. It is true that violence can be avoided through non-violent measures (for example, retreating), but these measures depend on having the requisite time and space. If an attack is in progress, this time and space may be lacking. It is true as well that violence need not be met directly with force. It may be redirected. Redirection, though, usually requires skill; it certainly requires presence of mind, which is not the natural mental state when faced with a sudden violent attack. Fourth, attacks are likely to occur outside of the presence of armed State agents. Muggings do not occur in front of uniformed police officers. It is likely that only the victim of violent aggression and other proximate individuals will be in a position to repel the aggression.

\section{B. MORAL IMPLICATIONS OF THE BASIC FACTS}

Given these realities of our condition, our intuition is doubtless that individuals should be entitled to defend themselves physically from wrongful aggression. That intuition, while fundamentally correct, requires some sharpening. Self-defence covers four sets of circumstances - defence of the person, defence of property, putative defence of the person, and putative defence of property. In the former two cases, the defence is against actual threats. In the latter two cases, the defence is against mistakenly perceived threats. It will be 
assumed that the sources of the threats are human agents. The four types of defence are unified in that they are all instances of defence by the self (with or without the assistance of other ordinary citizens).

\section{DEFENCE OF THE PERSON}

The paradigm case of self-defence is defence of the person against an actual threat. The moral account of this type of self-defence has two aspects - the first directed towards the aggressor and his or her act; the second directed towards the State. The account begins with the acceptance (or presupposition) that human life is valuable. Each person's life is valuable, although each person has a special responsibility to attend to his or her own life. Outside of duties or commitments one might have to family members, friends, or even one's country, ${ }^{2}$ no one has any obligation to sacrifice himself or herself for others. No one's life is more valuable - as human life - than any other person's life. If human life (existence, wellbeing) is good, right actions are those that promote life. In a self-defence situation, the defender is confronted by acts that injure or threaten to injure his or her life or well-being. The defender is justified in defending against those acts, because that defence promotes his or her life or well-being. There is no requirement in all cases to explore retreat before action, since the assumption is that the aggression has come upon the defender; the circumstances of self-defence tend to make the possibility of retreat impractical. Defence of the person against an actual threat should be classified as a justification (rather than an excuse), since the ends sought are right. ${ }^{3}$

The argument encounters a difficulty at this point. The defensive acts may not only neutralize the injurious acts but may injure the aggressor. In some cases, the harm caused to the aggressor would be only incidental — the focus of the defender's attention was on eliminating the injurious acts. In other cases, though, the aggressor is a direct target of defensive action - the defender seeks to kill or injure the aggressor, to stop the aggressor from engaging in further injurious conduct. But the aggressor is a person, and his or her life is valuable too. Why should the defender's life be priorized over the aggressor's? This is the paradox at the heart of the self-defence provisons.

A response is available for less serious self-defence cases, in which the injurious acts are the primary target of defence. In these cases, the defender's acts are right, since they promote human good. The aggressor's acts are not promoting good (except perhaps the aggressor's

2 Chief Justice Lord Coleridge stated that “[T]o preserve one’s life is generally speaking a duty, but it may be the plainest and the highest duty to sacrifice it”: R. v. Dudley and Stephens (1884), 14 Q.B. Div. 273 at 287 [Dudley and Stephens]. On the issue of self-sacrifice, see Luis E. Chisea, "Duress, Demanding Heroism and Proportionality: The Erdemovic Case and Beyond” (2007) Pace University, online: Pace University <http://digitalcommons.pace.edu/cgi/viewcontent.cgi?article=1403\&context=lawfaculty> at 8-9.

3 On the justification/excuse distinction, see Wayne N. Renke, "Calm Like a Bomb: An Assessment of the Partial Defence of Provocation” (2010) 47 Alta. L. Rev. 729 at 750-67. This article will rely on the discussion in that earlier work, and will offer no additional theoretical elaboration. See also Suzanne Uniacke, Permissible Killing: the self-defence justification of homicide (New York: Cambridge University Press, 1994) at 25, 29, 35, 41. One feature of self-defence as a justification is that third parties are entitled to assist the defender - this is expressed in the Canadian self-defence provisions - see e.g. the Criminal Code, R.S.C. 1985, c. C-46, ss. 37-41; see also Francisco Muñoz Conde, "Putative Self-Defense: A Borderline Case Between Justification and Excuse” (2008) 11 New Crim. L. Rev. 590 at 591. 
own good); they injure others. These acts are not justified. Morally justified actions (the actions constituting defence) should be recognized as superior to, or as having priority over, actions that are not morally justified. ${ }^{4}$ But since the aggressor's well-being is at stake, for the defensive action to remain justified the defensive action must not cause injury beyond that required to neutralize the injurious action. The justification concerns only "necessary" conduct. In other words, the defensive action must "minimally impair" the interests of others. Since defenders are being forced to defend themselves, in more-or-less unanticipated circumstances involving high emotion and probable impaired cognitive functioning because of stress, the assessment of the appropriateness of the defender's conduct cannot involve too fine a metric. As has been so often repeated, “[d]etached reflection cannot be demanded in the presence of an uplifted knife."5

In serious cases, the aggressor becomes the target of the defence. The defensive acts are intended to injure or kill the aggressor so that he or she no longer poses a threat. The approach is the same as in less serious cases. The defence is targeted at the source of injurious acts. Because of the nature of the threats the aggressor poses, the only practical way to neutralize the injurious conduct is to neutralize the aggressor. The aggressor qua person is not subordinated to the defender. The aggressor, though, is not justified in continuing to threaten injury to others. The aggressor's conduct and disposition are morally subordinated to efforts to limit that conduct and those threats.

Ordinarily, given that the defender and aggressor are members of a body politic, the work of neutralizing the aggressor's threat would be accomplished by State agents, who hold the monopoly on the use of instruments of violence. At least if political society is conceived along Lockean lines, we give up our rights to engage in self-help to defend ourselves in exchange for the protection offered by the State. ${ }^{6}$ In self-defence circumstances, however, the State is not present to assist. While we might have a general duty to refrain from selfhelp, if the State cannot assist and if we are left at serious risk, that duty should be suspended. By dealing with the aggressor's illegitimate interferences with others, the defender is doing what the State should be doing, but cannot do.

\section{DEFENCE OF PROPERTY}

Defence of property is assessed along lines similar to defence of the person. It, like defence of the person, is a justification. The main difference between defence of property and A further aspect of the subordination of the aggressor's actions to the actions of the defender is that the
aggressor, because of his or her aggression, could be said to "deserve" a forceable response. This issue will not be pursued further here, but it is likely that the retributivist punishment theory literature could shed some light on the responses that the aggressor's conduct could rightly be judged to attract keeping in mind that self-defence is defence, not punishment.

5 Brown v. United States, 256 U.S. 335 at 343 (1921). Justice Martin of the Ontario Court of Appeal wrote to the same effect in R. v. Baxter (1975), 27 C.C.C. (2d) 96 at para. 45 (Ont. C.A.) [Baxter]: "[I]n deciding whether the force used by the accused was more than was necessary in self-defence under both ss. 34(1) and 34(2), the jury must bear in mind that a person defending himself against an attack, reasonably apprehended, cannot be expected to weigh to a nicety, the exact measure of necessary defensive action"; see also R. v. Bogue (1976), 13 O.R. (2d) 272 at paras. 18, 20 (C.A.) [Bogue]; R. v. Deegan (1979), 17 A.R. 187 at paras. 113-14 (C.A.) [Deegan].

$6 \quad$ J. Locke, "The Second Treatise of Government: An Essay Concerning the True Original, Extent, and End of Civil Government,” in Two Treatises of Government, revised ed. by P. Laslett (Scarborough, Ontario: New American Library, 1965) 305 at 367. 
defence of the person is that defence of property relies not, or not only, on the value of human life and well-being, but on the value of property as a means of securing the good life for persons. Property may be an extension of will and personality. ${ }^{7}$ It is a psychological and physical necessity. ${ }^{8}$ Furthermore, it may be that it is an institution that should be preserved, because of the threat to public order if it is disturbed. In any event, property is an institution that should be defended. Illegitimate actions that threaten it may be neutralized, as may be actions that threaten life. A distinction between defence of property and defence of the person is that property is less valuable than life. It serves well-being and may be necessary to well-being, but it is a subordinate means, not an independent source of value. It may be that legitimate efforts to block interferences with property result in injury or death to the aggressor. However, the target of defence of property must be the interference only. Defence of property should not involve the intentional killing of the aggressor. The property at risk is not superior to the life of the aggressor. If, however, the measures by which an aggressor pursues an attack on property constitute an attack on the person of the property-holder, defence of the person is engaged.

\section{PutAtive SelF-Defence}

Putative defence of the person and defence of property may be considered together. In these instances, the defender is not faced with an actual threat of injury. Instead, the defender wrongly believes that he or she is faced with a threat. The defender's actions in this case are not justified. The defender is not doing the right thing — he or she is doing what is wrong because he or she is mistaken about the actions of others. Yet putative self-defence exonerates - not because it is a justification, but because it is an excuse. ${ }^{9}$ The foundation for the excuse is twofold. First, people make mistakes, as this defender did in fact. So long as the mistake was reasonable in the circumstances - a mistake that the "ordinary person" could have made - the mistake could (if about the right matters) excuse. Second, the mistake is about critical facts. In putative self-defence circumstances, the defender intentionally applies force to an aggressor, possibly injuring or killing the aggressor. This conduct would be an offence, except that the attribution of responsibility demands that an offender have known what the relevant circumstances were. If a defender's mistake concerned whether he or she were under attack, if that belief were reasonable, if his or her response was based on that belief, and if the response would have been appropriate if the facts as the defender believed them to be were true, the defender may be excused from responsibility for his or her actions.

\section{RESUlt OF THE AsSESSMENT}

The basic facts of the human condition, coupled with the value of life, and the value of property as contributing to the good life, yield the justifications of defence of the person and defence of property and the excuses of putative defence of the person and defence of property. These defences permit self-help to prevent interferences with life, well-being, and property, and absolve from responsibility so long as the defensive actions involve no more

Hegel's Philosophy of Right, trans. by T.M. Knox (New York: Oxford University Press, 1981) 42 at paras. 45-46.

Hart, supra note 1 at 196-97.

Conde, supra note 3 at 592-93; Uniacke, supra note 3 at 41. 
interference with the aggressor's rights than is reasonably necessary. These defences, one might say, form part of the "minimum natural law." ${ }^{10}$ Moreover, these defences should be reflected in any minimum positive penal law. ${ }^{11}$ No legal system could command any allegiance if it lacked some form of these protections. The criminal laws of Spain and Canada both should, and do, recognize self-defence.

\section{FORMAL SIMILARITIES AND DIFFERENCES}

An obvious starting point for comparison is that both Spain and Canada have codified criminal law. Spain has two main codes - the Código Penal, which covers substantive criminal law (offences and punishments) ${ }^{12}$ and is rationally organized on the continental model, and the Ley de Enjuiciamiento Criminal, or criminal procedure code. ${ }^{13}$ Canada has its Criminal Code, which covers both substantive and procedural law, ${ }^{14}$ and was common law Canada's first piece of legislation to approximate the continental code model. ${ }^{15}$ Not all criminal defences have made their way into the Criminal Code, but self-defence has - both Spain and Canada have codified the defence. In Spanish criminal law, self-defense is regulated by art. 20.4 of the Código Penal. Article 20.4 provides an exemption from criminal responsibility to those who defend themselves or their property or defend others or their property, if each of the following circumstances is satisfied:

1. [The defender must have responded to] [u]nlawful aggression. In the case of defending "goods" [defensa de los bienes], an attack that constitutes a crime [delito] or misdemeanour [faltas] and that threatens grave danger of imminent injury or loss is deemed to be unlawful aggression. In the case of defending a dwelling or units in a dwelling, unlawful entry is deemed to be unlawful aggression.

2. The means used to prevent or repel the aggression were rationally necessary.

3. Lack of "sufficient” provocation [[f]alta de provocación suficiente] by the defender. ${ }^{16}$

The Canadian law of self-defence is found in ss. 34 to 42 of the Criminal Code (reproduced in the appendix). ${ }^{17}$

Hart, supra note 1 at 193, 199.

John Finnis, “Natural Law Theories” in Stanford Encyclopedia of Philosophy (2008), section 1.4, online: Standford University <http://plato.stanford.edu/entries/natural-law-theories/>.

Ley Orgánica 10/1995, de 23 de noviembre, del Código Penal, online: Noticias Juridicas, Base de Datos de Legislación <http://noticias.juridicas.com/base_datos/Penal/lo10-1995.html> [Código Penal].

Ley de Enjuiciamiento Criminal promulgada por Real Decreto de 14 septiembre de 1882, online: Noticias Juridicas, Base de Datos de Legislación <http://noticias.juridicas.com/>.

Supra note 3.

See R.C. van Caenegem, European Law in the Past and the Future: Unity and Diversity over Two Millennia (New York: Cambridge University Press, 2002) at 40.

Supra note 12, art. 20.4 [translated by author]:

El que obre en defensa de la persona o derechos propios o ajenos, siempre que concurran

los requisitos siguientes:

1.Agresión ilegítima. En caso de defensa de los bienes se reputará agresión ilegítima el

ataque a los mismos que constituya delito o falta y los ponga en grave peligro de deterioro

o pérdida inminentes. En caso de defensa de la morada o sus dependencias, se reputará

agresión ilegítima la entrada indebida en aquélla o éstas.

2.Necesidad racional del medio empleado para impedirla o repelerla.

3.Falta de provocación suficiente por parte del defensor.

Sections 27 and 27.1 of the Criminal Code, supra note 3, could also be deployed in self-defence circumstances (the latter respecting offences on board aircraft). These provisions concern the use of force to prevent the commission of an offence. We will not, however, refer to these provisions in this discussion. 
Some initial high-level observations respecting the Spanish and Canadian law of selfdefence may be offered. In both Spain and Canada, self-defence is a "general" defence, available in relation to a variety of charges, including assault and homicide offences. If made out, the defence supports a complete acquittal. In both jurisdictions, the tactical burden of adducing evidence lies on the accused. ${ }^{18}$ In Spain as in Canada, the accused is acquitted if a reasonable doubt arises on the evidence; if self-defence is in issue on the evidence, the prosecution has the burden of disproving its availability. ${ }^{19}$ This result follows under the application of the in dubio pro reo principle in Spanish law — "any doubts or deadlocks must be decided in favour of the defendant." ${ }^{20}$ The principle is not set out in the Código Penal, but is an example of unwritten Spanish criminal law.

An immediate contrast with Canadian law is that Spain has a single self-defence provision, whereas the Canadian Criminal Code employs nine separate sections. A product of the Canadian statutory profusion is its complication and inconsistency, as Lamer C.J.C. has noted:

\begin{abstract}
As a preliminary comment, I would observe that ss. 34 and 35 of the Criminal Code are highly technical, excessively detailed provisions deserving of much criticism. These provisions overlap, and are internally inconsistent in certain respects. Moreover, their relationship to s. 37 (as discussed below) is unclear. It is to be expected that trial judges may encounter difficulties in explaining the provisions to a jury, and that jurors may find them confusing. The case at bar demonstrates this. During counsel's objections to his charge on ss. 34 and 35, the trial judge commented, "Well, it seems to me these sections of the Criminal Code are unbelievably confusing.” I agree with this observation.
\end{abstract}

Despite the best efforts of counsel in the case at bar to reconcile ss. 34 and 35 in a coherent manner, I am of the view that any interpretation which attempts to make sense of the provisions will have some undesirable or illogical results. It is clear that legislative action is required to clarify the Criminal Code's self-defence regime. $^{21}$

The state of Canada's self-defence legislation makes comparison difficult. Nonetheless, comparisons may still be essayed under some doctrinal themes.

Carlos Gómez-Jara Díez \& Luis E. Chiesa, “Spanish Criminal Law” in K.J. Heller \& M.D. Dubber, eds., The Handbook of Comparative Criminal Law (Stanford University Press, 2009) 4 at 29, also available online: Social Science Research Network <http://papers.ssrn.com/sol3/papers.cfm?abstract_id= 1317689>.

$19 \quad$ Bogue, supra note 5 at para. 16; Deegan, supra note 5 at paras. 83, 106-108.

20 Elena Merino-Blanco, Spanish Law and Legal System, 2d ed. (London: Sweet \& Maxwell, 2006) at 169, see also at 143, 158; Díez \& Chiesa, supra note 18 at 29; Kevin M. Clermont \& Emily Sherwin, "A Comparative View of Standards of Proof” (2002) 50 Am. J. Comp. L. 243 at 246. It should be noted that art. 24(2) of the Spanish Constitution provides as follows [emphasis added]:

all persons have the right of access to the ordinary judge predetermined by law; to the defence and assistance of a lawyer; to be informed of the charges brought against them; to a public trial without undue delays and with full guarantees; to the use of evidence appropriate to their defence; to not make self incriminating statements; to not declare themselves guilty; and to be presumed innocent. The Spanish Constitution, online: Tribunal Constitucional de España <http://85.62.99.51/Lists/const PDF/ConstitucionINGLES.pdf $>$.

21 R. v. McIntosh, [1995] 1 S.C.R. 686 at paras. 16-17 [McIntosh]. More than a decade ago, Justice Canada recommended amendments to the self-defence provisions: see Justice Canada, Reforming Criminal Code Defences: Provocation, Self-defence and Defence of Property, (Consultation Paper) (Ottawa: Department of Justice, Canada, 1998). Neither this recommendation nor the Chief Justice's observations have engaged federal legislative interest. 


\section{ASPECTS OF SELF-DEFENCE}

\section{A. Interests Protected}

Spanish and Canadian criminal law show some differences relating to the interests protected through self-defence. We will consider the notion of "legal goods" at work in Spanish criminal law and the law of self-defence; the preoccupations of the Canadian defence of property rules; and the potential ambit of protected interests under Spanish law.

\section{LEGAL GOODS}

The Canadian self-defence provisions deal with concrete interests - protection of the person (ss. 34, 35, 37), protection of personal property (ss. 38, 39), and protection of real property (ss. 40, 41, 42). ${ }^{22}$ The Spanish approach is more conceptual. The first clause of art. 20.4 refers to the defence of "goods" (los bienes). It is understood that "goods" means "legal goods” (bienes jurídicos), or values protected by law. ${ }^{23}$ This notion of legal goods requires some unpacking.

The notion of legal goods is of German derivation. ${ }^{24}$ German criminal law theory is influential in civil law countries, including Spain. ${ }^{25}$ According to Markus Dubber,

Rechtsgut, or legal good, is one of the foundational concepts underpinning the German criminal law
system.... Most fundamentally, the concept of legal good defines the very scope of criminal law. By common
consensus, the function of criminal law is the "protection of legal goods," and nothing else. Anything that
does not qualify as a legal good falls outside the scope of criminal law, and may not be criminalized. A
criminal statute, in other words, that does not even seek to protect a legal good is prima facie illegitimate. ${ }^{26}$

The very existence of the concept stands for the proposition that there are limits within which modern criminal law must operate if it is to claim legitimacy, and ultimately obedience, and therefore effectiveness. ${ }^{27}$

Dubber considers legal goods to be a foundational principle superior to the "harm principle," which has sometimes been invoked as having foundational status in the common law criminal law. ${ }^{28}$ Spanish criminal law recognizes two sorts of legal goods — individual legal goods and collective legal goods. Homicide offences, for example, are understood to protect the individual legal goods of persons' lives. Similarly, theft offences protect the

"A legal good is an interest that is worthy of the law's protection”: Luis E. Chiesa, “The Rise of Spanish and Latin American Criminal Theory” (2008) 11 New Crim. L. Rev. 363 at 366, n. 14. On the issue of which legal goods should and should not fall within province of the criminal law, see Santiago Mir Puig, "Legal Goods Protected by the Law and Legal Goods Protected by the Criminal Law as Limits to the State's Power to Criminalize Conduct” (2008) 11 New Crim. L. Rev. 409.

$24 \quad$ Markus Dirk Dubber, "Theories of Crime and Punishment in German Criminal Law” (2005) 53 Am. J. Comp. L. 679; see also Bernd Schünemann, "The System of Criminal Wrongs: The Concept of Legal Goods and Victim-based Jurisprudence as a Bridge between the General and Special Parts of the Criminal Code" (2004) 7 Buff. Crim. Law Rev. 551, online: Buffalo Criminal Law Center $<$ http://wings.buffalo.edu/law/bclc/bclrarticles/7/2/schuenemann.pdf $>$.

Dubber, ibid.

Ibid. at 683-84 [footnotes omitted].

Ibid. at 694

Ibid. at 682-83. 
individual good of property. In the cases of crimes against the administration of justice or environmental crimes, the goods protected are collective goods. Dubber admits that the nature and scope of legal goods (the set of limits on the criminal law) has not been satisfactorily explicated, going so far as to say that "[t]he notion of legal goods provides critical analysis of German criminal law with a language for expressing itself, no less, but also not much more.”29 Nonetheless, we can get some sense of the sorts of interests falling under the concept through some influential lists — for example:

human life, bodily integrity, personal freedom of action and movement, property, wealth, traffic safety, the incorruptibility of public officials, the constitutional order, the public peace, the external security of the state, the impunity of foreign state organs and indicia, the security of national, ethnic or cultural minorities against extermination or undignified treatment, international peace. ${ }^{30}$

And further:

[1]ife, bodily integrity, honor, the administration of law, ethical order, sexual autonomy, property, the state, the currency, dominant moral opinions, ... undisturbed operation of administration, ... public peace, traffic congestion, the life and well-being of animals, the environment, morality, "purity of soil, air, water, etc.," the variety of species in flora and fauna, maintenance of intact nature, the people's health, life contexts as such, purity of the system of proof. ${ }^{31}$

The Canadian position respecting the purposes of the criminal law may not be too removed from the Spanish-German position respecting legal goods. Our Supreme Court has ruled that the "harm principle" is not the foundational principle for criminal prohibitions. It is not a principle of fundamental justice under s. 7 of the Canadian Charter of Rights and Freedoms. $^{32}$ The limitation of harm to others is not the objective that must be served by criminal prohibitions. The State does have an interest in enacting criminal legislation to prohibit conduct that harms others, but harm to others is neither a necessary nor a sufficient condition for the legitimacy of criminal legislation. ${ }^{33}$ The sorts of interests that our courts have described as falling within the scope of legitimate criminal legislation for division of powers purposes are not much different than those falling within the German lists of legal goods:

For a law to be classified as a criminal law, it must possess three prerequisites: a valid criminal law purpose backed by a prohibition and a penalty (Reference re Firearms Act (Can.), [2000] 1 S.C.R. 783, 2000 SCC 31, at para. 27). The criminal power extends to those laws that are designed to promote public peace, safety, order, health or other legitimate public purpose. In RJR-MacDonald Inc. v. Canada (Attorney General), [1995] 3 S.C.R. 199, it was held that some legitimate public purpose must underlie the prohibition. In Labatt Breweries ... in holding that a health hazard may ground a criminal prohibition, Estey J. stated the potential

Ibid. at 694; "One problem with the theory of legal goods ... is that it is difficult, if not impossible, to agree with regard to which interests are in need of the criminal law's protection and which are not": Chisea, supra note 23 at 367 [footnotes omitted].

$30 \quad$ Hans-Heinrich Jescheck \& Thomas Weigend, Lehrbuch des Strafrechts: Allgemeiner Teil, 5th ed. (Berlin: Duncker \& Humblot, 1996) at 7, quoted in Dubber, supra note 24 at 684.

31 Dubber, ibid. at 685, drawing on Claus Roxin, Strafrecht: Allgemeiner Teil I, 3d ed. (Munich: C.H. Beck, 1997) at 12-23.

32 Part I of the Constitution Act, 1982, being Schedule B to the Canada Act 1982 (U.K.), c. 11.

33 R. v. Malmo-Levine; R. v. Caine, 2003 SCC 74, [2003] 3 S.C.R. 571 at paras. 111, 114, 130. 
purposes of the criminal law rather broadly as including "public peace, order, security, health and morality" (p. 933). ${ }^{34}$

Even if it is granted that the overall orientations of Canadian and Spanish criminal law are similar in terms of the legal goods the law promotes and protects, it remains that the Canadian self-defence provisions are more focused than the Spanish provisions - only persons and property are protected. In particular, the defence of property (or better, defence of possession) has special prominence in Canadian law.

\section{Preoccupations of The Canadian LAW OF SELF-Defence}

\section{a. Real Property}

Both the Spanish and Canadian laws of self-defence give special attention to the protection of dwellings. ${ }^{35}$ Protection of dwellings is the only specific situation mentioned in art. 20.4 of the Código Penal: "[i]n the case of defending a dwelling or units in a dwelling, unlawful entry is deemed to be unlawful aggression." 36 Dwellings are places where we should be specially protected. They should be (although they tragically are not for everyone) a safe habour. All others can be denied access without specific lawful authorization. ${ }^{37}$ We should be granted special scope to defend our dwellings against improper access. Article 20.4 uses broad language - "unlawful entry," which could include both forcible and non-forcible entries. Section 40 of the Criminal Code refers to repelling forcible breaking into or forcible entering of a dwelling house, ${ }^{38}$ while s. $41(1)$ refers to trespass only (which need not be forcible). Section 41(2) sets out a deemed assault provision similar in effect to that found in art. 20.4 - " "[a] trespasser who resists an attempt by a person who is in peaceable possession of a dwelling-house or real property, or a person lawfully assisting him or acting under his authority to prevent his entry or to remove him, shall be deemed to commit an assault without justification or provocation"(thereby making ss. 34 and 37 available to those in peaceable possession). ${ }^{39}$ The s. $41(2)$ provision, though, has a "resistance” precondition not found in art. 20.4 .

Even in relation to dwelling houses, however, Spanish and Canadian law differ. Spanish law attends to unlawful entry. The deemed assault would not occur if a person entered with permission (the entry was lawful) but the permission was subsequently terminated. While s.

Ibid. at para. 74

"[D]welling-house" is defined in s. 2 of the Criminal Code, supra note 3; generally, the term means "the whole or any part of a building or structure that is kept or occupied as a permanent or temporary residence"; homes have long been protected in the common law tradition: "That the house of every one is to him as his castle and fortress, as well for his defence against injury and violence, as for his repose": Semayne's Case (1604), 77 E.R. 194 at 196 (K.B.).

Supra note 12.

Thus, a "home invasion" committed in the course of specified offences is an aggravating factor in sentencing: Criminal Code, supra note 3, s. 348.1.

The offence provision relating to breaking and entering is s. 348 of the Criminal Code, ibid.

Ibid., s. 41(2). See Baxter, supra note 5 at para. 62 [emphasis in original]:

The meaning of this subsection is not entirely clear. I am disposed to think that its effect is not to convert mere passive resistance into an assault but merely to provide that if any force is used by the wrongdoer in resisting an attempt to prevent his entry or to remove him, such force is unlawful, and hence an assault. The amount of force that may be used to prevent or defend against any assault actually committed by the wrongdoer depends upon the ordinary principles of self-defence as set out in s. 34 of the Code. 
40 is similarly concerned only with unlawful entry, s. 41 not only authorizes force to prevent trespass, but to "remove a trespasser." ${ }^{40}$ Moreover, Canadian law does not restrict its explicit real property protections to dwellings. Section 41 protects those not only in peaceable possession of a dwelling-house, but those in peaceable possession of "real property,” without qualification. ${ }^{41}$ Canadian law gives greater explicit protection to real property interests than Spanish law.

\section{b. Peaceable Possession}

The defence of property provisions give abundant explicit protection to "peaceable possession," which is not mentioned at all in art. 20.4. ${ }^{42}$ The express protection of peaceable possession is also extended by Canadian law to personal property, which again receives no mention in art. 20.4. Both ss. 38 and 39 protect individuals in peaceable possession of personal property. Section 38 protects against trespass. Section 39 protects peaceable possession under a claim of right — even against a person entitled to the property. ${ }^{43}$ The defence of real property provisions also protect peaceable possession. Sections 40 and 41 protect peaceable possession of a dwelling-house. Section 41 additionally protects peaceable possession of (non-residential) real property.

Section 42 provides elaborate and remarkable protection to a person in peaceable possession. ${ }^{44}$ Under s. 42(1), a person entitled to lawful possession of the premises must enter peaceably and by day — otherwise, the entry is not justified, and would be an assault. Under s. 42(3), if a person having peaceable possession of the premises (or acting under authority of the person who does) assaults the person lawfully entitled to the premises who is seeking to enter peaceably and by day, the assault is deemed to be provoked — by the person lawfully entitled to the premises. ${ }^{45}$ This means that the person entitled to take possession cannot immediately respond as to an unprovoked assault (s. 34). Rather, since the person entitled to possession is deemed to be the "provoker," s. 35 applies; generally, he or she must

Along with provincial legislation, such as the Trespass to Premises Act, R.S.A. 2000, c. T-7, this section of the Criminal Code gives holders of real property the right to "trespass" undesirable individuals, and supports the right of security services to take trespassers off the property ("every one lawfully assisting him or acting under this authority”); see also the Petty Trespass Act, R.S.A. 2000, c. P-11, which creates both a trespass offence and a warrantless arrest authority (ss. 2, 4). See e.g. the potential use of s. 41 in relation to undeveloped land and irrigation works: R. v. Born With A Tooth (1992), 131 A.R. 193 (C.A.).

Código Penal, supra note 12; in the Canadian context, “peaceable possession” has been interpreted as follows: "For the purpose of the Code, the term must mean a possession not seriously challenged by others. If it were otherwise, then every property dispute could be resolved legitimately by force. The evident object of the law is the exact opposite: the defence should be available only to those whose possession has not been seriously questioned by somebody before the incident in question”: ibid. at para. 33.

43 " $[\mathrm{T}]$ here is clear and consistent authority that the term 'claim of right' embraces an honest although mistaken belief in entitlement to the property even though the mistake is based on an error of law or fact”: R. v. Lei (1997), Man. R. (2d) 81 at para. 20 (C.A).

44 The Canadian defence of real property provisions are anchored in statutes of venerable lineage, extending back to the Forcible Entry Acts of 1381, 1391, 1429, and 1623. These statutes restricted a landlord to making peaceable entry to retake land; if force were used, the landlord could be criminally liable: see Sir Robert Megarry \& H.W.R. Wade, The Law of Real Property, 4th ed. (London: Stevens \& Sons, 1975) at 656-57; see also Sir Robert Megarry \& H.W.R. Wade, The Law of Real Property, 7th ed., Charles Harpum, Stuart Bridge \& Martin Dixon, eds. (London: Sweet \& Maxwell, 2008) at 866 (para. 19-036).

45 In contrast, under the Criminal Code, supra note 3, s. 42(2), if a person does not have peaceable possession of the premises under a claim of right (or is not acting under the authority of one with claimof-right peaceable possession), an assault on the person lawfully entitled to possession entering peaceably by day is deemed to be without justification or provocation. 
retreat so far as is possible, and may justifiably use force only in the face of apprehended death or grievous bodily harm. ${ }^{46}$

\section{c. Observations Respecting Canadian Preoccupations}

One must concede that because of the generality of the drafting of art. 20.4 and its use of the notion of "legal good," it was not necessary for express references to be made to the varieties of protection for the possession of personal property and real property. Insofar as the possession of personal and real property are legal goods, and insofar as they are threatened by aggressive action, self-defence could be deployed. It is not the case that just because the various possessory interests are not mentioned, they are not protected.

That being said, it remains that while art. 20.4 addresses one clause specifically to property, Canadian law assigns two sections to personal property and three sections to real property. Parliament appears to have taken great pains to deal exhaustively with property issues. One might surmise that private property has a more pronounced cultural significance in Canada than in Spain. Furthermore, the Canadian provisions tend to support peaceable possession - even as against persons with legally superior entitlements. The policy reasoning behind the provisions appears to be that the cost of permitting self-help possessory remedies - presumably, the violence that would ensue in protection of possession exceeds the benefits of putting property into the possession of the person with the better claim.

The Canadian provisions could be taken to reflect the common law's focus on possession in the law of property. As regards real property, it has been observed that

\footnotetext{
English law ... has directed its attention not to ownership, but to possession, or, as it is called in the case of land, seisin. All titles to land are ultimately based upon possession in the sense that the title of the man seised prevails against all who can show no better right to seisin. Seisin is a root of title, and it may be said without undue exaggeration that so far as land is concerned there is in England no law of ownership, but only a law of possession. ${ }^{47}$
}

\section{More generally,}

[w] often hear it said ... that 'possession is nine-tenths of the law.' The mathematics behind that adage may be off (how can such a thing be calculated?), but the underlying sentiment is quite sound. Possession is a concept that is ubiquitous in the law of property, especially in relation to personalty, where its importance can be seen in the law of bailment, gifts, liens, and the sale of goods. Possession or the right to possession, not ownership or title per se, determines the ability of an owner (or other aggrieved person) to sue in tort in response to a wrongful interference with chattels. ${ }^{48}$

$46 \quad$ Section 35 will be discussed in Part IV.F, below.

47 E.H. Burn, ed., Cheshire and Burn's Modern Law of Real Property, 15th ed. (London: Butterworths, 1994) at 26.

48 Bruce Ziff, Principles of Property Law, 4th ed. (Scarborough, Ontario: Thomson Carswell, 2006) at 117 [footnotes omitted]. 
It may be that the common law and continental civil law do not have notions of possession and ownership as disparate as may sometimes be contended, ${ }^{49}$ so that the defence of property provisions may not turn on a fundamental distinction between the common law and Spanish civil law property traditions. At the very least though, the Canadian defence of property provisions have an organic relationship with the non-criminal law rules not evident on the face of art. 20.4. The relationship between the criminal law and property law rules would be worthy of further exploration, which will not be attempted here.

\section{THE AMBIT OF INTERESTS PROTECTED \\ UNDER THE SPANISH LAW OF SELF-DEFENCE}

As a result of the specificity of their drafting, the Canadian self-defence provisions are available only respecting certain threats of a physical nature to persons and property. These might be thought to be the only legal goods that should be protected through self-defence provisions. The Spanish rules, however, could potentially permit self-defence when interests other than protection of the person or property are engaged. Dubber has contended that since self-defence is "self" defence, the defence is not available respecting attacks on collective goods. ${ }^{50}$ However, the language of the Spanish provisions does not exclude the possibility of defence of collective goods, as when environmental damage is threatened. The defence, furthermore, might be extended to circumstances in which individual legal goods other than physical safety or possession of personal or real property are relevant. Conceivably, the Spanish provisions could be relied on if interests in intellectual property or in information were threatened by aggressive action (or better, "e-action”), as when illegitimate reproduction, access, or use of intellectual property or information occurs. Other nonphysical interests of a defender might be at stake, such as when the "honour" of the accused is threatened. "Honour" would have to be found by a court to be a protected individual legal good. $^{52}$ Thus, in Case 49/2003, 18th March, a decision of the Audiencia Provincial from Álava, the accused returned home to find his wife with one Iván. The accused wounded Iván twice with a knife. The accused's lawyer argued that his client sought to defend his honour. In rejecting this argument, the Court said that the accused's honour was already damaged. ${ }^{53}$

\section{B. THREATS TO INTERESTS}

Self-defence involves repelling an attack. In Spanish terms, to protect the legal good that is under attack, violence may be directed at the individual whose actions threaten that legal good. ${ }^{54}$ The threat posed by the aggressor has three main features that allow for varying

$49 \quad$ See James Gordley \& Ugo Mattei, “Protecting Possession” (1996) 44 Am. J. Comp. L. 293.

Dubber, supra note 24 at 693.

Extending (from a Canadian perspective) a sort of provocation defence into non-homicide cases.

The Código Penal, supra note 12, sets out a group of “crimes against honour" - Libro II, Titulo XI,

"Delitos contra el honor.” In Horder's view, the old common law of provocation was intimately linked to the protection of honour: J. Horder, Provocation and Responsibility (Oxford: Clarendon Press, 1992) at 34 .

53 Audiencia Provincial de Álava, Sentencia nº 49/2003, 18 de Marzo 2003, online: <http://www. audienciaprovincial.com/>; also online: Consejo General del Poder Judicial, Jurisprudencia de la Audiencia Nacional, Tribunales Superiores de Justicia y Audiencias Provinciales <http://www.poder judicial.es/search/indexAN.jsp>.

54 D. Luzón Peña, “El doble fundamento de la legítima defensa” (1977) Cuadernos de Política Criminal 130. 
legislative treatment — the nature of the aggression, the nature of the aggressor, and the aggressor's culpability.

\section{NATURE OF THE AgGRession}

A precondition for the availability of self-defence is that the aggression is not legally authorized. Otherwise, individuals would have licence to resist lawful authority. The Spanish approach to the illegality of the attack is in some respects broader than the Canadian approach, and in some respects narrower. Under art. 20.4, the attack must be a criminal offence (delito or falta). ${ }^{55}$ Particular offences are not specified. This contrasts with the approach in the Canadian defence of the person provisions. A particular predicate offence is specified - assault. ${ }^{56}$ Presumably, any of the modalities of assault (non-consensual application of force; threatening to apply force; accosting, impeding, or begging while openly wearing or carrying a weapon $)^{57}$ could fall within the ambit of the "assault" that engages selfdefence. ${ }^{58}$ This, again, is some indication that the Spanish provision protects a broader set of legal goods than the Canadian provisions, which appear designed to protect physical wellbeing alone.

In contrast, the defence of property provisions concern interferences with immediate rights of possession. The threatening acts may be, but need not be criminal offences. Under s. 39(1), the act resisted is that of the person legally entitled to the personal property. Under s. 41 , the conduct referred to is "trespassing," which is not a criminal offence. ${ }^{59}$ As discussed above, s. 42 deals with the case of a person lawfully entitled to enter real property, who, even if entering peaceably by day, can be deemed to be a "provoker." The broad ambit of potential triggers for defence of property underlines the extensive protection of possessory rights extended by Canadian criminal law.

\section{NATURE OF THE AGgRESSOR}

Canadian self-defence law and commentary tends to assume that the aggressor is a competent adult. Spanish commentators add clarifications that might seem a bit unexpected, but are basically in line with Canadian law. For instance, the aggressor must be a natural person, not a corporation. ${ }^{60}$ Spanish criminal law does not recognize corporate liability, so 55 Delitos are classified into delitos grave - the most serious offences - and delitos menos grave. Faltas
are the least serious offences. As in Canadian criminal law, the most serious offences attract the most severe penalties and the most complex procedures; the least serious offences attract lower penalties and simplified procedures: see Código Penal, supra note 12, arts. 13, 33.

$56 \quad$ Criminal Code, supra note 3, ss. 34(1), 34(2), 37. Section 35 does not refer to assault, but does refer to conduct that could be so characterized - violent conduct that gives rise to the reasonable apprehension of death or grievous bodily harm.

Ibid., ss. 265 (a), (b), and (c), respectively.

Kent Roach, Criminal Law, 4th ed. (Toronto: Irwin Law, 2009) at 298.

There is an offence labelled "Trespassing at Night," but this concerns loitering or prowling at night on the property of another person near a dwelling-house, without lawful excuse: Criminal Code, supra note 3, s. 177; trespassing is an offence under provincial legislation: see the Petty Trespass Act and the Trespass to Premises Act, supra note 40.

$60 \quad$ Joaquín Cuello Contreras, El Derecho Penal Español: Parte General, Tomo I (Madrid: Dykinson, 2002) at 807; Díez \& Chiesa, supra note 18 at 32. 
this point is not surprising. ${ }^{61}$ It is theoretically possible under Canadian law for a corporation to be convicted of assault, if the conditions in s. 22.2 were satisfied (for example, if a corporation hires goons to attack protesters), ${ }^{62}$ but the self-defence provisions themselves contemplate physical action against a physical foe, not against a legal entity.

The aggressor cannot be an animal, such as a dog. ${ }^{63}$ In case 16/2000, 4th February, from the Audiencia Provincial, Seville, ${ }^{64}$ a dog's owner let it run free without a muzzle and leash. The dog attacked a child (who was less than six years old). The child's grandfather injured the dog with a knife. After being taken to a veterinarian, the dog died. The dog's owner sought damages. ${ }^{65}$ The grandfather succeeded on the ground of self-defence, not directly because of the attack by the dog, but because of the acts or omissions of the owner, who failed to control the animal. In Canadian terms, the dog's owner could be considered to have committed an assault through the doctrine of innocent agency. ${ }^{66}$ This case points towards another feature of Spanish law — it is conceivable, as in a case like this, that the "unlawful aggression" supporting self-defence stems from an omission (for example, the failure to control a dangerous animal) rather than a positive act (as would usually be the case with an assault).

\section{Culpability OF THE AgGRESSOR}

The position under Spanish law appears to be that if the aggressor is a child under the age of criminal responsibility or an individual who is not criminally responsible on account of mental disorder — or, for that matter, an individual operating under non-mental disorder automatism, or who has some other available defence - self-defence would not be available because none of these individuals could commit an offence against the defender. ${ }^{67}$ At this point, we will ignore the possibility that the defender was not aware of such deficiencies of

61 Díez \& Chiesa, ibid. at 26; Uria Menéndez, “Criminal Liability of Companies Survey” (2008), online: Lex Mundi <http://www.lexmundi.com/images/lexmundi/PDF/Business_Crimes/Crim_Liability_Spain. pdf>.

$62 \quad$ Criminal Code, supra note 3, s. 22.2:

In respect of an offence that requires the prosecution to prove fault - other than negligence an organization is a party to the offence if, with the intent at least in part to benefit the organization, one of its senior officers

(a) acting within the scope of their authority, is a party to the offence;

(b) having the mental state required to be a party to the offence and acting within the scope of their authority, directs the work of other representatives of the organization so that they do the act or make the omission specified in the offence; or

(c) knowing that a representative of the organization is or is about to be a party to the offence, does not take all reasonable measures to stop them from being a party to the offence. Contreras, supra note 60 at 807; Díez \& Chiesa, supra note 18 at 32.

Audiencia Provincial de Sevilla, Nº de Resolución: 16/2000, 4th February, online: Consejo General del Poder Judicial, Jurisprudencia de la Audiencia Nacional, Tribunales Superiores de Justicia y Audiencias Provinciales <http://www.poderjudicial.es/search/indexAN.jsp>.

This is possible within Spanish criminal procedure - the complainant may be a party to the proceedings, and may raise a civil claim within those proceedings: see Código Penal, supra note 12, arts. 109-26; Merino-Blanco, supra note 20 at 141-42.

R. v. Toma, 2000 BCCA 494, 147 C.C.C. (3d) 252 at paras. 18-20; R. v. Devgan (2007), 53 C.R. (6th) 104 at paras. 7-11 (Ont. Sup. Ct. J.).

M. Olmedo Cardenete, “Comentario al artículo 20.4 del Código Penal,” Comentarios al Código Penal, Volumen II (Madrid: Edersa, 1999) 303 at 312. This also appears to be the result under the German law of self-defence, which requires a "wrongful" action that - ex hypothesi - the "exempt" aggressor could not commit: see Russell L. Christopher, "Tripartite Structures of Criminal Law in Germany and Other Civil Law Jurisdictions” (2007) 28 Cardozo L. Rev. 2675 at 2682. The relevant provisions of the German Penal Code are ss. 32-35: see Edward M. Wise, Penal Code of the Federal Republic of Germany, trans. by Joseph J. Darby, online: Buffalo Criminal Law Center < http://wings.buffalo.edu/ law/bclc/Germind.htm>. 
capacity, and assume that the defender knew that the aggressor was not competent to commit an offence or knew that no defence was at law available to the aggressor. The Canadian position is not settled. Eric Colvin and Sanjeev Anand comment as follows:

\begin{abstract}
The various defences in the Code impose the condition that force be used in response to an "assault" or for the prevention of an "offence”. Ordinarily such terms identify a form of culpability as well as of conduct. In this context, however, they may be taken to refer merely to conduct. There does not appear to be any Canadian authority on this point. It would, however, be absurd to deny a defence to someone who, for example, uses force in warding off the attack of a mentally disordered person just because that person is entitled to a defence of mental disorder for the attack. It has been generally accepted at common law that defensive force may be used against any wrongful conduct, even though there may be some exculpatory defence to that conduct. It is to be expected that the Code will be interpreted in the same manner. ${ }^{68}$
\end{abstract}

In any event, even if in the rare circumstances under consideration the defence of selfdefence would not be available to a defender, neither the law of Spain nor the law of Canada would leave the defender wholly defenceless. For example, under Canadian law, the defence of necessity might be relied on. Assuming, for example, that an armed aggressor were obviously psychotic, delusional, and threatened imminent harm, a defender could kill to save himself or herself, assuming no non-lethal alternatives were available. A difficulty is that the Canadian defence of necessity has not yet been extended to permit the taking of life. ${ }^{69}$ More precisely, the Canadian defence of necessity has a proportionality requirement (unlike the self-defence rules) and "the harm inflicted must be less than the harm sought to be avoided." ${ }^{70}$ If lives are of equal moral weight, the taking of another's life to preserve one's own may not be a choice of a lesser evil. In Dudley and Stephens, the taking of an innocent life to preserve others in extreme jeopardy was held not to be protected under the defence of necessity. ${ }^{71}$ Nonetheless, the judgment ties personal self-defence to the doctrine of necessity, carrying this linkage back to Bracton and Hale. ${ }^{72}$ Old formulations of the self-defence doctrine permitting defensive killing are close to our current necessity doctrine, and it is

68 Eric Colvin \& Sanjeev Anand, Principles of Criminal Law, 3rd ed. (Scarborough, Ontario: Thomson Carswell, 2007) at 306 [footnote omitted]. Colvin and Anand do refer to R. v. Paice, 2005 SCC 22, [2005] 1 S.C.R. 339 [Paice], which has aspects that may tend in the contrary direction. In Paice, Charron J. confirmed that $R$. v. Jobidon, [1991] 2 S.C.R. 714 judicially negates manifest consent to fight only if bodily harm is intended and it is actually inflicted (para. 12). If a consensual fight occurs but no bodily harm is caused by a participant — even if he or she intended to cause bodily harm — the consent will negate the actus reus of assault (para. 18). If an aggressor and a defender have agreed to fight, but the aggressor does not cause bodily harm, the aggressor could rely on consent - the aggressor would not commit "assault." Hence, s. 34(1) would not be available, because the defender would not be "assaulted.” Moreover, if the defender had consented to fight, s. 34(1) would not be available, because the consent to fight amounts to provocation of the aggressor (this would be a case of mutual provocation): "Where a person willingly engages in mutual combat, he cannot later say that he did not provoke the assault” (para. 20 [citations omitted]). Strictly speaking, in the consent and no-bodily-harm circumstances, there could be no provocation of an assault since no assault occurred. If the defender did not consent to fight, even if the aggressor did not cause bodily harm, the aggressor would commit an assault and s. 34(1) would remain open to the defender (para. 4). [Ruzic]; on the availability of a necessity defence under German law, see Christopher, supra note 67 at 2684-89; Antje du Bois-Pedain, “Intentional Killings: The German Law” in J. Horder, ed. Homicide Law in Comparative Perspective (Portland, Oregon: Hart, 2007) 55 at 59-61. Perka, ibid. at 253.

Dudley and Stephens, supra note 2; see also Chisea, supra note 2 at 8-9. Dudley and Stephens, ibid. at 282-83. 
possible that necessity could therefore be relied on, not as against a wholly innocent victim, but as against a victim who is not legally culpable but whose conduct poses grave risk. ${ }^{73}$

\section{MISTAKE BY THE DEFENDER}

The preceding discussion has assumed that the aggressor was in fact attacking the defender or was interfering with his or her property. As discussed in Part I above, however, the defender may have erred — the defender may have mistaken the identity of the aggressor and harmed the wrong person; the defender may have misconstrued conduct as seriously threatening; and the defender may have been actually under attack and have intended to repel the actual aggressor, but harmed an innocent third party instead. The aggressor may have purposefully tricked the defender into believing that the aggressor had the means to do the defender serious injury. Again, as indicated above, the defender's conduct may be excused, so long as the mistake was reasonable or non-negligent. Spanish law will treat the nonnegligent defender as entitled to rely on the defence of self-defence. ${ }^{74} \mathrm{~A}$ defender is entitled to rely on s. 34(2) of the Criminal Code if he or she reasonably apprehended death or grievous bodily harm and believed on reasonable grounds that he or she could not preserve himself or herself except through deadly force - and if the defender reasonably believed that he or she was being assaulted. ${ }^{75} \mathrm{~A}$ defender who makes a reasonable mistake about the existence of an assault may also rely on s. 34(1). ${ }^{76}$

\section{TIME CONSTRAINTS}

Self-defence has temporal requirements. The Canadian defence, on its face, requires that the aggression and the response be close in time. Subsection 34(1) refers to a person who "is unlawfully assaulted"; s. 34(2) also refers to a person "who is unlawfully assaulted and who causes death or grievous bodily harm in repelling the assault." 77 In Spanish terms, between aggression and defence there must be a unity of action (entre la agresión y la defensa haya una unidad de acto).$^{78}$ To fall within the scope of statutory protection, self-defensive conduct cannot occur too long after an attack or too long before an attack.

In Re A (Children), [2000] EWCA Civ 254, [2001] 2 W.L.R. 480 (C.A.), online: British and Irish Legal Information Institute <http://www.bailii.org/ew/cases/EWCA/Civ/2000/254.html>, while acknowledging authority against the proposition that life may be sacrificed for life in circumstances of duress or necessity, Ward L.J. did leave open the possibility of the licit killing of the innocent to save another: part IV, sections 7.7, 7.8, and 8 (Brooke and Walker LL.J. concurring in separate judgments). Chisea argues that if a defence is understood as an excuse rather than as a justification (i.e., the claim is for forgiveness, not acknowledgement that what was done was right), the case is stronger for permitting the defence to extend to homicide offences (the accused is only claiming that he or she did what anyone else would have done in the circumstances): Chisea, supra note 2 at 21.

$74 \quad$ Conde, supra note 3 at 603-604.

75 R. v. Malott, [1998] 1 S.C.R. 123 at para. 18 [Malott]; R. v. Pétel, [1994] 1 S.C.R. 3 at 15-16 [Pétel]; R. v. Reilly, [1984] 2 S.C.R. 396 at 404; Roach, supra note 58 at 301.

$76 \quad$ "I think I should add that, contrary to the view expressed by the trial Judge, s. 34(1) does not import a purely objective test. The doctrine of mistake of fact is applicable to s. 34(1) as well as s. 34(2). An accused's belief that he was in imminent danger from an attack may be reasonable, although he may be mistaken in his belief": Baxter, supra note 5 at para. 45; see also R. v. Nelson (1992), 8 O.R. (3d) 364 at para. 18 (C.A.) [Nelson]; R. v. Kong, 2005 ABCA 255, 371 A.R. 90 at para. 186, aff'd 2006 SCC 40, [2006] 2 S.C.R. 347 [Kong]; Don Stuart, Canadian Criminal Law, 5th ed. (Scarborough, Ontario: Thomson Carswell, 2007) at 495.

Criminal Code, supra note 3.

78 Tribunal Supremo Sala II de lo Penal, Sentencia 1861/2001, de 17 de octubre, online: Noticias Juridicas $<$ http://sentencias.juridicas.com/>; see Díez \& Chiesa, supra note 18 at 32. 
The self-defence rules are not to protect revenge. Assuming that an attack is over and there is no threat that it will be resumed or repeated, self-defence will not exonerate retaliation. ${ }^{79}$

Pre-emptive self-defence poses difficulties. On the one hand, the law should not require defenders to be actually assaulted — and potentially badly injured — before permitting defensive measures. Indeed, Canadian criminal law does permit pre-emptive self-defence, if the defender believes, on reasonable grounds, that he or she will be imminently attacked. ${ }^{80}$ Spanish law extends the same accommodation to the defender. ${ }^{81}$

On the other hand, the law should not allow pre-emptive measures to be taken too long before a predicted attack. ${ }^{82}$ If measures are undertaken too early, they may be motivated more by retaliation for a previous attack than by a fear of a coming attack. Moreover, the greater the gap between the measures and the predicted onset of the attack, the greater the probability that the attack would not have in fact occurred, and the higher the likelihood that the defender could have employed measures to avoid injury other than physical violence directed at the predicted aggressor.

Nonetheless, the Supreme Court of Canada has ruled that there is no requirement that the danger be "imminent." The imminence of the danger is simply a factor to be considered on the issues of the accused's reasonable beliefs concerning the degree of danger, and his or her options in the face of the danger. ${ }^{83}$ The Supreme Court has extended defence of the person protection to well before a predicted attack, in circumstances in which, on the evidence, the defender's conduct was constrained by battered spouse syndrome. ${ }^{84}$ In these circumstances, the evidence tends to show that the defender can predict impending violence accurately, having experienced the patterns or cycles of preparation, violence, and contrition many times over. The evidence supports the conclusion that the state of mind of the defender was such that her options were restricted - she had nowhere else to go. She could not just leave. Violence was the only option.

It appears that Spanish law would not extend the self-defence doctrine to battered spouse circumstances. Article 20.4 does refer to "grave danger of imminent injury or loss," not expected injury or loss - y los ponga en grave peligro de deterioro o pérdida inminentes. ${ }^{85}$ This does not entail that no defence would be available to a battered spouse. The defence of necessity, provided under art. 20.5, could be extended. The defence is available respecting threats posed by human agents. ${ }^{86}$ Article 20.5 provides that a person is exempted from criminal liability if:

F. Muñoz Conde \& M. García Arán, Derecho Penal: Parte General, 7th ed. (Valencia: Tirant Lo Blanch, 2007) 339; Díez \& Chiesa, ibid. at 32.

Kong, supra note 76 at para. 186; Colvin \& Anand, supra note 68 at 308; Roach, supra note 58 at 299. Conde, supra note 3 at 606.

Contreras, supra note 60 at 815.

Pétel, supra note 75 at 15-17; R. v. Lavallee, [1990] 1 S.C.R. 852 at 876 [Lavallee] [emphasis in original]: "It will be observed that s. 34(2)(a) does not actually stipulate that the accused apprehend imminent danger when he or she acts. Case law has, however, read that requirement into the defence"; see also Stuart, supra note 76 at 504-509.

Malott, supra note 75 at para. 20; Lavallee, ibid. at 889-90.

Código Penal, supra note 12.

Díez \& Chiesa, supra note 18 at 30. 
(i) a legal good is threatened,

(ii) harm must be caused to another legal good to avoid injury to that good,

(iii) the evil caused is not greater than the evil avoided,

(iv) the circumstances of necessity were not caused intentionally by the person, and

(v) the person was not obligated by his or her position to accept the injury. ${ }^{87}$

The excusing necessity provisions of the German Penal Code have been applied in battered spouse circumstances. ${ }^{88}$

\section{E. REASONABLENESS OF RESPONSE}

Article 20.4 does not impose a "proportionality" requirement on the response to aggression. ${ }^{89}$ Rather, the measures employed must have been "rationally necessary" (necesidad racional del medio empleado para impedirla o repelerla). While preserving his or her own interests, the defender must limit the injury to the aggressor's interests to the greatest degree possible in the circumstances.

The only Canadian self-defence provision with an express proportionality requirement is s. 37(2), which applies to the use of force to defend oneself or anyone under one's protection. Section 37(2) provides that "[n]othing in this section shall be deemed to justify the wilful infliction of any hurt or mischief that is excessive, having regard to the nature of the assault that the force used was intended to prevent." ${ }^{\text {"0 }}$ Otherwise, the Canadian provisions employ language similar to the "necessity" formulation in art. 20.4. Section 34(1) authorizes force not intended to cause death or grievous bodily harm that is "no more than is necessary to

Código Penal, supra note 12 [translated by author]:

El que, en estado de necesidad, para evitar un mal proprio o ajeno lesione un bien juridico de otra persona o infrinja un deber, siempre que concurran los siguientes requisitos:

(1) Que el mal causado no sea mayor que el que se trate de evitar.

(3) Que la situación de necesidad no haya sido provocada intencionadamente por el sujeto.

(3) Que el necesitado no tenga, por su oficio o cargo, obligación de sacrificarse.

See also Díez \& Chiesa, ibid. at 30. On the final condition relating to the accused's position, the following comments are apt: "The [duty] to control the instinct of self-preservation is ... required of those who have assumed the obligation to tolerate [threats] in light of their profession, even when the threats endanger their lives. [The reason for this is that] it is in precisely these circumstances when the community should be able to rely on them" (H.H. Jescheck \& T. Weigend, Tratado de Derecho Penal, trans. by O. Cardenete, 5th ed. (Albolote, Spain: Comares, 2003) at 523, cited in Chisea, supra note 2 at 41).

du Bois-Pedain, supra note 69 at 59, n. 21:

This solution is confirmed in BGHSt 48, 255 (BGH 1 StR 489/02 - judgment of 25 Mar 2003:

"family tyrant"), where the Federal Court of Justice denied a frightened and subjectively helpless woman who killed her husband in his sleep after she had endured years of physical abuse the justificatory [necessity] defence of $\S 34$, but quashed her conviction for voluntary manslaughter on the basis that $\S 35$ [excusing necessity] might apply if she subjectively believed that there was no other way for her to escape from her husband's violence, and this assessment of her situation was either correct or reasonable in the circumstances. (§ 32 [self-defence] could not apply in the defendant's favour because she killed her husband outside the context of a present or immediately anticipated unlawful attack on her). 
enable [the defender] to defend himself." 91 The "no more force than is necessary" language is used in s. 37(1) (defence of others) and s. 41(1) (defence of dwelling-house or real property); s. 40 uses "as much force as is necessary." 92 Section 34(2), which depends on a reasonable belief that the defender will suffer death or grievous bodily harm and, on a reasonable belief that the defender cannot otherwise preserve himself or herself, permits the intentional causation of death or grievous bodily harm. ${ }^{93}$ No proportionality requirement must be satisfied. $^{94}$

Under Canadian law, the use of force in the defence of real property cases could excuse homicide or the infliction of grievous bodily harm so long as these results were not intended. If deadly force were intended, s. 34(2) would apply and its requirements would have to be made out on the evidence. ${ }^{95}$ Under Spanish law, killing to preserve property would not be excused. Life is a more valuable legal good than property. ${ }^{96}$

Canadian law would stand with Spanish law on the impropriety of permitting killing in defence of personal property. Section 38(1) of the Criminal Code provides a defence to a person in peaceable possession of personal property (and to those assisting that person). The defence extends to preventing a trespasser from taking the property, or taking the property back from the trespasser - so long as, in either case, the person "does not strike or cause

Baxter, supra note 5 at para. 43:

A person defending himself against an unprovoked assault who did not intend to cause death or grievous bodily harm and who accidentally causes death or grievous bodily harm is entitled to invoke s. 34(1). If the force used was no more than was necessary for the purpose of self-defence, it is justifiable under s. 34(1) and is hence lawful. If a person doing a lawful act accidentally kills or causes grievous bodily harm then (in the absence of criminal negligence) the death or grievous bodily harm is caused by misadventure or accident and no criminal liability is incurred.

See also Kong, supra note 76 at paras. 181, 192, 208 (What is measured is the force used, not the consequences produced); Colvin \& Anand, supra note 68 at 309.

92 "Necessity" is not measured by a strict standard: see Baxter, ibid.; Kong, ibid. at para. 216: "the need for a tolerant approach is to be remembered when measuring the proportionate force." See also Roach, supra note 58 at 300 . Generally, what is "necessary" is what was reasonable in all of the circumstances, including the subjective beliefs of the defender: R.v. Szczerbaniwicz, 2010 SCC 15, [2010] S.C.J. No. 15 (QL) at para. 21.

93 "Under s. 34(2) a person who is unlawfully assaulted is justified even if he intentionally kills or intentionally causes bodily harm to his assailant subject to the conditions specified in that subsection": Baxter, ibid. at para. 42.

$94 \quad$ Bogue, supra note 5 at paras. 14, 26. See also para. 25 [emphasis in original]:

Whether the amount of force used against the accused was disproportionate to the nature of the force used by her was proper to be considered by the jury as a circumstance, or an item of evidence, in deciding whether she had a reasonable apprehension of death or grievous bodily harm and whether she had reasonable and probable grounds to believe that she could not otherwise preserve herself from death or grievous bodily harm. If, however, the jury was either satisfied that the accused had such apprehension and belief, or entertained a reasonable doubt with respect to it, she was entitled to be acquitted. No further requirement existed that the force used by the accused be proportionate to the nature of the attack upon her.

95 "It is common ground between the parties that the intentional killing of a trespasser could only be justified where the person in possession of the property is able to make out a case of self-defence": $R$. v. Gunning, 2005 SCC 27, [2005] 1 S.C.R. 627 at para. 26; "Firing at a mere trespasser is, of course, not justifiable, and the trial Judge in the circumstances of this case correctly charged the jury that killing or causing grievous bodily harm to a trespasser could only be justified in self-defence": Baxter, supra note 5 at para. 60; see Colvin \& Anand, supra note 68 at 329; Roach, supra note 58 at 309. Justice LeBel would agree: "No modern case asserts that a threat of harm to an accused's property is enough to invoke the defence": Ruzic, supra note 69 at para. 69. The Supreme Court has cautioned against an excessively restrictive approach to justifiable force in defence of property in $R$. $v$. McKay, 2007 SCC 16, [2007] 1 S.C.R. 793 at para. 2: "we should not be taken as endorsing the view that 'defence of property alone will never justify the use of anything more than minor force being used against a trespasser' ... or that, in all cases, 'the defence of property alone will not justify the intentional use of a weapon against a trespasser."” 
bodily harm to the trespasser." 97 Under s. 38(2), if the person in peaceable possession does lay hands on the property, and if the trespasser persists in trying to take it away, the trespasser is deemed to commit an assault without justification or provocation. This brings the circumstances under s. 34(1).

\section{F. Provocation BY THE DEFENDER}

Both Spanish and Canadian criminal law operate under the same principle respecting the role of provocation by the defender in self-defence cases, but the Spanish provisions achieve somewhat greater simplicity than do the Canadian. The principle is that a person should not be entitled to rely on self-defence if he or she has provoked the aggression subsequently defended against. One might say that exoneration should not be available if the defender is the author of his or her own misfortune - or, given that it is the aggressor who is injured, the author of the aggressor's misfortune.

“Sufficient provocation” disqualifies conduct as self-defence under art. 20.4. "Sufficient provocation" appears to be conduct by the defender that a reasonable person would consider likely to elicit an aggressive response from the aggressor; that is, the aggressive response "was a reasonably foreseeable consequence of the defender's conduct." ${ }^{98}$ Article 20.4 does not limit provocations to illegal acts. Neither, though, does art. 20.4 require that the provocation be intentional, although it may be; the issue is whether the aggressive response was reasonably predictable.

If the drafting of s. 34(2) were corrected and it did not apply if the defender provoked the assault to which he or she responds, the scheme of the Criminal Code would be tolerably clear. Under s. 36, "[p]rovocation includes, for the purposes of sections 34 and 35, provocation by blows, words or gestures." 99 As in Spanish law, there is no limitation of provocative acts to blows, words, or gestures, or to illegal acts. ${ }^{100}$ It has been asserted that provocation means conduct "intended ... to provoke an assault," ${ }^{101}$ which would exclude negligent provocations. Under s. 35, if the defender did provoke the aggressor (or if the defender "started it," and first assaulted the aggressor, but without intent to cause death or grievous bodily harm), the defender would be exonerated for using force against the aggressor's response to his or her initial acts, if:

(a) he [or she] uses the force

under reasonable apprehension of death or grievous bodily harm from the violence of the person whom he [or she] has assaulted or provoked, and 
(b) he [or she] did not, at any time before the necessity of preserving himself from death or grievous bodily harm arose, endeavour to cause death or grievous bodily harm; and

(c) he [or she] declined further conflict and quitted or retreated from it as far as it was feasible to do so before the necessity of preserving himself [or herself] from death or grievous bodily harm arose. ${ }^{102}$

The complication introduced by the drafting error in s. 34(2) is that this subsection - on a plain reading — is also available even if the defender provoked the aggressor or "started it.”103

Section 34(2) matches s. 35 by requiring the same reasonable fear of death or grievous bodily harm and the same reasonable belief that the only available response is deadly force, but it does not disqualify the defender from its protection if the defender had earlier attempted to cause death or grievous bodily harm, and it does not require the defender to have attempted to retreat.

\section{G. IMPERFECT SELF-DEFENCE}

The evidence may be found not to support self-defence. That does not mean that the evidence relevant to self-defence has no other relevance or use in the proceedings. An accused may lose the protection of self-defence because his or her conduct was not confined to what was necessary — he or she went beyond defence through an intention to injure. ${ }^{104}$ An accused who engages in "excessive" self-defence may be guilty of homicide. Under Spanish law, absent specified aggravating circumstances, the accused would not be guilty of the most serious level of homicide; the accused may face punishment of 10-15 years imprisonment, as opposed to 15-20 years imprisonment. ${ }^{105}$ The emotions and confusion of the self-defence circumstances, even if the accused's conduct has exceeded the limits of a rational necessary response, could negate the mental requirements for the most serious form of homicide.

Article 21 of the Código Penal deals with “imperfect” defences, including self-defence. The evidence relating to self-defence, even though all of its requirements were not made out, may be considered as extenuating circumstances for sentencing purposes. ${ }^{106}$ Under art. 68, these circumstances may reduce the penalty for the offence by one or two "grades," or levels. ${ }^{107}$

Criminal Code, supra note 3, s. 35.

McIntosh, supra note 21.

Tribunal Supremo Sala II de lo Penal. Sentencia 544/2007, de 21 de junio, online: <http://sentencias. juridicas.com/index.php>. The animus laedendi is not included within the scope of defence of the person.

See Código Penal, supra note 12, arts. 138-39.

"Son circunstancias atenuantes ... Las causas expresadas en el capítulo anteriro, cuando no concurrieren todos los requisitos necesarios para eximir de responsabilidad en sus respectivos casos”: ibid., art. 21.1. "En los casos previstos en la circunstancia primera del artículo 21, los jueces o tribunales impondrán la pena inferior en uno o dos grados a la señalada por la ley, atendidos el número y la entidad de los requisitos que falten o concurran, y las circunstancias personales de su autor, sin perjuicio de la aplicación del artículo 66 del presente Código”: ibid., art. 68. 
The Canadian position is similar to the Spanish. Canada has no partial defence of "excessive force in self-defence" that would reduce liability from what would otherwise be murder to manslaughter. ${ }^{108}$ But failure to succeed on self-defence does not entail liability for murder as opposed to manslaughter. The Crown must still prove the requisite intent:

It does not follow automatically, however, that the verdict must be murder. The accused has become responsible for a killing. He has no justification on the basis of self-defence, but unless it is shown that the killing was accompanied by the intent required under s. 212(a) of the Code, it remains a killing without intent, in other words manslaughter. If the jury considers that excessive force has been used, and has resulted in a death, they must then ask themselves whether the accused in causing the killing possessed the intent described in s. 212(a) of the Code, that is, an intent to kill or cause bodily harm likely to cause death. If they are satisfied beyond a reasonable doubt that the intent was present, they should find the accused guilty of murder. However, in the event they found no such intent existed, or had a doubt as to its existence, they should convict of manslaughter. ${ }^{109}$

Evidence relevant to self-defence may also be relevant to the issue of the accused's mens rea. Evidence falling short of supporting self-defence could still assist in negating (for example) the inference that the accused did intend to kill the aggressor or that accused planned and deliberated the killing of the aggressor:

\begin{abstract}
The separate and cumulative effect on intention of alcohol or drug consumption, mental illness or mental disorder, provocation and excessive force used in self-defence must be left with the finder of fact. None of these factors is sufficient in itself to be a defence or partial defence. One of them may have a bearing on whether the accused had the intent for murder. See $R$. v. Nealy (1986), 30 C.C.C. (3d) 460 (Ont. C.A.)... Even if the words and actions of the deceased did not raise a reasonable doubt in the mind of the trier of fact as to whether the accused had been provoked or that the accused was incapable of forming the requisite intent by reason of consumption of alcohol, the trier of fact was nevertheless still required to consider all those surrounding circumstances in coming to a conclusion as to whether the accused had the requisite intent needed to commit murder. ${ }^{110}$
\end{abstract}

Evidence relevant to self-defence may also be relevant to sentencing.

\title{
V. Conclusion
}

Violence is part of the human condition, as is dealing with that violence. Spain and Canada have adopted mutually recognizable means of providing for self-defence in the criminal law. Where we differ, we betray our cultural dispositions. Where we are similar, we express a common project of life and law. as follows: "Everyone who is authorized by law to use force is criminally responsible for any excess thereof according to the nature and quality of the act that constitutes the excess." 
Appendix A:

Self-Defence Provisions in the Criminal Code (Canada)

\section{DEFENCE OF PERson}

\section{Self-defence against unprovoked assault}

34. (1) Every one who is unlawfully assaulted without having provoked the assault is justified in repelling force by force if the force he uses is not intended to cause death or grievous bodily harm and is no more than is necessary to enable him to defend himself.

Extent of justification

(2) Every one who is unlawfully assaulted and who causes death or grievous bodily harm in repelling the assault is justified if

(a) he causes it under reasonable apprehension of death or grievous bodily harm from the violence with which the assault was originally made or with which the assailant pursues his purposes; and

(b) he believes, on reasonable grounds, that he cannot otherwise preserve himself from death or grievous bodily harm.

$$
\text { R.S., 1985, c. C-46, s. 34; 1992, c. 1, s. 60(F). }
$$

\section{Self-defence in case of aggression}

35. Every one who has without justification assaulted another but did not commence the assault with intent to cause death or grievous bodily harm, or has without justification provoked an assault on himself by another, may justify the use of force subsequent to the assault if

(a) he uses the force

(i) under reasonable apprehension of death or grievous bodily harm from the violence of the person whom he has assaulted or provoked, and

(ii) in the belief, on reasonable grounds, that it is necessary in order to preserve himself from death or grievous bodily harm;

(b) he did not, at any time before the necessity of preserving himself from death or grievous bodily harm arose, endeavour to cause death or grievous bodily harm; and

(c) he declined further conflict and quitted or retreated from it as far as it was feasible to do so before the necessity of preserving himself from death or grievous bodily harm arose. 


\section{Provocation}

36. Provocation includes, for the purposes of sections 34 and 35, provocation by blows, words or gestures.

$$
\text { R.S., c. C-34, s. } 36 .
$$

\section{Preventing assault}

37. (1) Every one is justified in using force to defend himself or any one under his protection from assault, if he uses no more force than is necessary to prevent the assault or the repetition of it.

\section{Extent of justification}

(2) Nothing in this section shall be deemed to justify the wilful infliction of any hurt or mischief that is excessive, having regard to the nature of the assault that the force used was intended to prevent.

$$
\text { R.S., c. C-34, s. } 37 .
$$

\section{DEFENCE OF PROPERTy}

\section{Defence of personal property}

38. (1) Every one who is in peaceable possession of personal property, and every one lawfully assisting him, is justified

(a) in preventing a trespasser from taking it, or

(b) in taking it from a trespasser who has taken it,

if he does not strike or cause bodily harm to the trespasser.

\section{Assault by trespasser}

(2) Where a person who is in peaceable possession of personal property lays hands on it, a trespasser who persists in attempting to keep it or take it from him or from any one lawfully assisting him shall be deemed to commit an assault without justification or provocation.

R.S., c. C-34, s. 38.

\section{Defence with claim of right}

39. (1) Every one who is in peaceable possession of personal property under a claim of right, and every one acting under his authority, is protected from criminal responsibility for defending that possession, even against a person entitled by law to possession of it, if he uses no more force than is necessary. 


\section{Defence without claim of right}

(2) Every one who is in peaceable possession of personal property, but does not claim it as of right or does not act under the authority of a person who claims it as of right, is not justified or protected from criminal responsibility for defending his possession against a person who is entitled by law to possession of it.

R.S., c. C-34, s. 39.

\section{Defence of dwelling}

40. Every one who is in peaceable possession of a dwelling-house, and every one lawfully assisting him or acting under his authority, is justified in using as much force as is necessary to prevent any person from forcibly breaking into or forcibly entering the dwelling-house without lawful authority.

R.S., c. C-34, s. 40.

\section{Defence of house or real property}

41. (1) Every one who is in peaceable possession of a dwelling-house or real property, and every one lawfully assisting him or acting under his authority, is justified in using force to prevent any person from trespassing on the dwelling-house or real property, or to remove a trespasser therefrom, if he uses no more force than is necessary.

\section{Assault by trespasser}

(2) A trespasser who resists an attempt by a person who is in peaceable possession of a dwelling-house or real property, or a person lawfully assisting him or acting under his authority to prevent his entry or to remove him, shall be deemed to commit an assault without justification or provocation.

R.S., c. C-34, s. 41.

\section{Assertion of right to house or real property}

42. (1) Every one is justified in peaceably entering a dwelling-house or real property by day to take possession of it if he, or a person under whose authority he acts, is lawfully entitled to possession of it.

\section{Assault in case of lawful entry}

(2) Where a person

(a) not having peaceable possession of a dwelling-house or real property under a claim of right, or

(b) not acting under the authority of a person who has peaceable possession of a dwelling-house or real property under a claim of right, 
assaults a person who is lawfully entitled to possession of it and who is entering it peaceably by day to take possession of it, for the purpose of preventing him from entering, the assault shall be deemed to be without justification or provocation.

\section{Trespasser provoking assault}

(3) Where a person

(a) having peaceable possession of a dwelling-house or real property under a claim of right, or

(b) acting under the authority of a person who has peaceable possession of a dwelling-house or real property under a claim of right,

assaults any person who is lawfully entitled to possession of it and who is entering it peaceably by day to take possession of it, for the purpose of preventing him from entering, the assault shall be deemed to be provoked by the person who is entering.

R.S., c. C-34, s. 42. 